\title{
PURIFICATION AND CHARACTERIZATION OF VIRGINIAE BUTANOLIDE C-BINDING PROTEIN, A POSSIBLE PLEIOTROPIC SIGNAL-TRANSDUCER IN STREPTOMYCES VIRGINIAE
}

\author{
Hyun Soo Kim ${ }^{\dagger}$, Hideaki Tada, TakuYa Nihira and Yasuhiro Yamada* \\ Department of Fermentation Technology, Faculty of Engineering, Osaka University, \\ 2-1 Yamada-oka, Suita-shi, Osaka 565, Japan
}

(Received for publication December 8, 1989)

\begin{abstract}
Virginiae butanolide $\mathrm{C}$ (VB-C) is an autoregulator which triggers virginiamycin production in Streptomyces virginiae. A new binding assay with tritium-labeled VB-C analogue (2,3-cis-2-(1'hydroxy-[6',7'- $\left.{ }^{3} \mathrm{H}\right]$ heptyl)-3-(hydroxymethyl)butanolide) was developed and a specific VB-C binding protein was purified to homogeneity from crude extracts of $S$. virginiae by ammonium sulfate fractionation, DEAE-Sephacel and Sephadex G-100 column chromatographies, hydrophobic HPLC on phenyl $5 \mathrm{PW}$ and native polyacrylamide gel electrophoresis. The VB-C binding protein showed an apparent $\mathrm{M}_{\mathrm{r}}$ of 35,800 on sodium dodecyl sulfate-polyacrylamide gel electrophoresis, and $\mathrm{M}_{\mathrm{r}}$ of $26,000 \sim 44,000$ on native molecular sieve HPLC, indicating the monomeric nature of the binding protein. The binding protein efficiently bound to a $\mathrm{VB}$ affinity column and eluted specifically by VB-C, which confirmed the specific nature of the binding protein. The binding activity decreased by $40 \%$ in the presence of genomic DNA from $S$. virginiae, indicating interaction between the VB-C binding protein and the DNA.
\end{abstract}

Streptomycetes are Gram-positive bacteria characterized by their versatile ability to produce secondary metabolites as well as their morphological complexity. One of the most interesting features of these microorganisms is their production of endogeneous and exogeneous signal molecules which switch on several phenotypes, such as antibiotic production and the formation of aerial mycelia. These signal molecules have sometimes been called "autoregulators" ", and those so far isolated and chemically identified are as follows: A-Factor from Streptomyces griseus, which triggers production of streptomycin and the formation of aerial mycelia ${ }^{3)}$, anthracycline-inducing factors from Streptomyces viridochromogenes ${ }^{4}$, Streptomyces bikiniensis and Streptomyces cyaneofuscatus ${ }^{5}$, B-factor which induces rifamycin production in Nocardia $\mathrm{sp}^{6}{ }^{67}$, pamamycin which stimulates aerial mycelia formation in Streptomyces alboniger ${ }^{8}$, virginiae butanolides A, B, C, D, E (VB-A $\sim$ E) from Streptomyces virginiae, which trigger production of virginiamycin $^{9,10)}$, and IM-2 which induces blue pigment production in Streptomyces sp. FRI-5 ${ }^{11}$ (Fig. 1). Except B-factor and pamamycin, all the other autoregulators have a structure of 2,3-disubstituted $\gamma$-butyrolactone, and as many as $25 \%$ of actinomycetes produce either VBs, A-factor or anthracycline-inducing factors as signal molecules ${ }^{3,12,13)}$. Therefore, $\gamma$-butyrolactone-type signal molecules are distributed widely in Streptomyces species, and play an important role in secondary metabolism and morphological differentiation. However, little is known of the fundamental mechanism by which they exert their pleiotropic effects. Recently, we have shown the existence of a VB-C binding protein in crude extracts of $S$. virginiae ${ }^{14}$. To know more about the VB-C binding protein, in this study we have purified it to homogeneity and characterized it. We believe that this study on the VB-C binding protein serves as a

$\uparrow$ Present address: Department of Food Technology, College of Engineering, Kyungnam University, 449 Wolyoung-dong, Masan, 630-701, Korea. 
Fig. 1. Structures of several autoregulators isolated from Streptomyces.

A-Factor from S. griseus<smiles>CC(C)CCCCC(=O)C1C(=O)OC[C@H]1CO</smiles>

Factor I from $S$. viridochromogenes<smiles>CC(C)CCCC[C@H](O)[C@H]1C(=O)OCC1CO</smiles>

Factors from $S$. bikiniensis and $S$. cyaneofuscatus<smiles>CC(C)CCC[C@@H](O)[C@H]1C(=O)OC[C@H]1CO</smiles><smiles>CC(C)CCCC[C@@H](O)[C@H]1C(=O)OC[C@H]1CO</smiles><smiles>CC(C)CCCCC[C@H](O)[C@H]1C(=O)OC[C@H]1CO</smiles>

Virginiae butanolides from S. virginiae<smiles>CC(C)CCC[C@@H](O)[C@H]1C(=O)OC[C@H]1CO</smiles>

VB-A<smiles>CCC(C)CCC(O)[C@H]1C(=O)OC[C@H]1CO</smiles>

VB-B<smiles>CCCCC[C@H](O)[C@H]1C(=O)OC[C@H]1CO</smiles>

VB-C<smiles>CCCCCCC(O)[C@H]1C(=O)OC[C@H]1CO</smiles>

VB-D<smiles>CC(C)CCC(O)[C@H]1C(=O)OC[C@H]1CO</smiles>

VB-E

From Streptomyces sp. FRI-5<smiles>CCCC(O)C1C(=O)OC[C@@H]1CO</smiles>

IM-2

model case in elucidating the mechanism of regulation exerted by autoregulators having a $\gamma$-butyrolactone ring.

\section{Materials and Methods}

\section{Strain and Cultivation Conditions}

S. virginiae of YANAGImoto and TERUI ${ }^{15,16)}$ was used throughout this study as a source of VB-C binding protein. This strain was grown at $28^{\circ} \mathrm{C}$ in a medium containing Bacto-casitone (Difco) $7.5 \mathrm{~g}$, yeast extract $7.5 \mathrm{~g}$, glycerol $15 \mathrm{~g}$ and $\mathrm{NaCl} 2.5 \mathrm{~g}$ per liter, $\mathrm{pH} 6.5$. For large scale cultivation, 1,200 liters of the medium in a 2,000-liter fermenter was inoculated with 100 liters of seed culture, and cultivated at $28^{\circ} \mathrm{C}$ for 8 hours. The cells were harvested by continuous centrifugation $(13,000 \times g)$ and stored at $-20^{\circ} \mathrm{C}$ until use. About $24 \mathrm{~kg}$ of wet mycelium was obtained from 1,200 liters broth.

\section{Chemicals and Standard Proteins}

All the chemicals were reagent or HPLC grade, obtained either from Nacalai Tesque, Inc. (Osaka, Japan) or Wako Pure Chemical Industries, Ltd. (Osake, Japan) and used without further purification. 
Radio-inert VB-C and the tritium-labeled VB-C analogue $\left(2,3-c i s-2-\left(1^{\prime}-h y d r o x y-\left[6^{\prime}, 7^{\prime}-{ }^{3} \mathrm{H}\right]\right.\right.$ heptyl)-3hydroxymethyl)butanolide, $\left.\left[{ }^{3} \mathrm{H}\right] \mathrm{VB}-\mathrm{C}_{7}\right)(54.6 \mathrm{Ci} / \mathrm{mmol})$ were chemically synthesized as described $\left.{ }^{14,17}\right)$. Optically active VB-A, B, B', C and D were a gift from Prof. MoRI ${ }^{18)}$. Marker proteins for sodium dodecyl sulfate-polyacrylamide gel electrophoresis (SDS-PAGE), native PAGE and molecular sieve HPLC were purchased from Pharmacia LKB, Sigma Chemical Co. and Oriental Yeast Co., Ltd., respectively. Genomic DNA of $S$. virginiae was isolated from the mycelia by lysing with lysozyme-EDTA-SDS according to HUNTER ${ }^{19}$. DNA concentration was determined spectrophotometrically at $260 \mathrm{~nm}$ taking $\mathrm{OD}=1$ as $50 \mu \mathrm{g}-\mathrm{DNA} / \mathrm{ml}$.

\section{$\left[{ }^{3} \mathrm{H}\right]$ VB- $\mathrm{C}_{7}$ Binding Assay and Protein Assay}

VB binding activity was routinely assayed by measuring the difference between binding of $\left[{ }^{3} \mathrm{H}\right] \mathrm{VB}-\mathrm{C}_{7}$ in the absence and presence of non-labeled VB-C. A typical assay mixture contained $100 \mu 1$ of the binding protein solution and $69.6 \mathrm{nM}\left[{ }^{3} \mathrm{H}\right] \mathrm{VB}-\mathrm{C}_{7}(54.6 \mathrm{Ci} / \mathrm{mmol})$ in $0.05 \mathrm{M}$ triethanolamine- $\mathrm{HCl}(\mathrm{pH} 7.0)$ containing $0.5 \mathrm{M} \mathrm{KCl}, 5 \mathrm{~mm}$ dithiothreitol, $0.1 \mathrm{~mm}$-amidinophenylmethanesulfonyl fluoride hydrochloride (Buffer A). The assay mixtures in $1.5 \mathrm{ml}$-Eppendorf micro test tubes were incubated for 20 minutes at $25^{\circ} \mathrm{C}$ in the presence and absence of 1,800-fold non-labeled VB-C $(0.125 \mathrm{~mm})$. The protein-ligand complex was then precipitated by the addition of $900 \mu \mathrm{l}$ of $80 \%$ saturated ammonium sulfate in $0.05 \mathrm{M}$ triethanolamine- $\mathrm{HCl}$ containing $0.5 \mathrm{M} \mathrm{KCl}(\mathrm{pH} 7.0)$. The precipitate was collected by centrifugation at $10,000 \times g$ for 5 minutes, washed with $1.0 \mathrm{ml}$ of $80 \%$ saturated ammonium sulfate in $0.05 \mathrm{M}$ triethanolamine- $\mathrm{HCl}$ containing $0.5 \mathrm{M}$ $\mathrm{KCl}$ to remove unbound $\left[{ }^{3} \mathrm{H}\right] \mathrm{VB}-\mathrm{C}_{7}$, and recollected by centrifugation as described above. The precipitate was dissolved in $100 \mu \mathrm{l}$ of distilled water, and the radioactivity in the solution was measured with a liquid scintillator (Beckman LS7500) in the presence of $10 \mathrm{ml}$ toluene containing Omnifluor ( $4 \mathrm{~g} / \mathrm{liter}$, New England Nuclear) and Triton X-100 (500 g/liter).

Protein concentration was determined by a dye-binding assay with the Bio-Rad protein assay kit using bovine serum albumin as a standard.

Purification Procedure

All procedures were carried out at $0 \sim 4^{\circ} \mathrm{C}$ unless otherwise specified.

Step 1. Preparation of Cell-free Extract: Cells ( $500 \mathrm{~g}$-wet weight) were suspended in 2.5 liters of Buffer A, and disrupted by passing twice through a Dyno-Mill homogenizer (type KDL, Willy A Bachofen AG., Basel, Switzerland) at a flow rate of $70 \mathrm{ml} /$ minute. Cell debris was removed by centrifugation at $28,000 \times g$ for 20 minutes.

Step 2. Ammonium Sulfate Fractionation: To the supernatant from Step 1, solid ammonium sulfate was added with gentle strring to give $30 \%$ saturation. After standing for 1 hour, the precipitate was removed by centrifugation at $28,000 \times g$ for 20 minutes, and the ammonium sulfate concentration was then increased to $50 \%$ saturation by the addition of solid ammonium sulfate with gentle stirring while keeping $\mathrm{pH}$ at 7.0. After standing for 1 hour, the precipitate was collected by centrifugation at $28,000 \times g$ for 20 minutes, and dissolved in a minimum amount of Buffer $\mathrm{A}$. The solution was dialyzed for 12 hours against 2 changes of 20 -fold volume of $0.05 \mathrm{M}$ triethanolamine- $\mathrm{HCl}(\mathrm{pH} 7.0)$ containing $5 \mathrm{mM}$ dithiothreitol and $0.1 \mathrm{~mm}$ p-amidinophenylmethanesulfonyl fluoride hydrochloride (Buffer $\mathrm{B}$ ) to remove ammonium sulfate.

Step 3. First DEAE-Sephacel Chromatography: The dialyzed solution from Step 2 was concentrated by ultrafiltration (UK-10, MW cut 10,000, Advantech Toyo). The concentrated solution was adsorbed batchwise to 1 liter of DEAE-Sephacel (Pharmacia LKB) preequilibrated with Buffer B for 1 hour with gentle stirring. After washing with 3 liters of Buffer $B$, the adsorbed protein was eluted successively with each 3 liters of Buffer B containing $0.1,0.2$ and $0.3 \mathrm{M} \mathrm{KCl}$. The $\mathrm{VB}$ binding activity was present in the $0.3 \mathrm{M} \mathrm{KCl}$ eluates, and the eluates were concentrated by ultrafiltration and dialyzed as described above. Steps 2 and 3 were necessary to remove major contaminating proteins.

Step 4. Second DEAE-Sephacel Column Chromatography: The dialyzed solution from Step 3 was applied onto a DEAE-Sephacel column $(5.1 \times 60 \mathrm{~cm})$ previously equilibrated with Buffer B. After washing with 3 liters of Buffer $B$, the protein was subsequently eluted with 6 liters of a linear gradient of potassium chloride from 0 to $0.4 \mathrm{M}$ in Buffer $\mathrm{B}$ in fractions of $18 \mathrm{ml}$ (Fig. 2) at a flow rate of $60 \mathrm{ml} /$ hour. VB binding activity were eluted at $0.3 \sim 0.34 \mathrm{M} \mathrm{KCl}$, and fractions $310 \sim 364$ were pooled and concentrated as described above. 
Step 5. Gel Filtration on a Sephadex G-100 Column: The concentrated solution from Step $4(37.5 \mathrm{ml})$ was applied onto a column of Sephadex G-100 $(5.1 \times 63 \mathrm{~cm})$ preequilibrated with Buffer A, and eluted with the same buffer in fractions of $14 \mathrm{ml}$ (Fig. 3) at a flow rate of $40 \mathrm{ml} /$ hour. Active fractions (fractions No. $42 \sim 62$ ) were pooled and concentrated to $21 \mathrm{ml}$ by ultrafiltration.

Step 6. Hydrophobic HPLC on a Phenyl 5PW Column: The concentrated solution from Step 5 was purified in aliquots of $50 \mu \mathrm{l}(1 \mathrm{mg}$ of protein) per run on a phenyl $5 \mathrm{PW}$ column $(7.5 \times 75 \mathrm{~mm}$, Tosoh Manufacturing Co., Ltd.) with a linear gradient of ammonium sulfate concentration from 1 to $0 \mathrm{M}$ in Buffer B containing $0.3 \mathrm{M} \mathrm{KCl}$ at a flow rate of $0.5 \mathrm{ml} /$ minute (Fig. 4). Protein in the eluate was monitored at $280 \mathrm{~nm}$ with a UV detector (Uvidec-100-V, Japan Spectroscopic Co., Ltd.). VB binding activity appeared at around 70 minutes.

\section{Effect of Genomic DNA on the VB-C Binding Activity}

VB-C binding assay was perforemed with the concentrated sample from phenyl 5PW HPLC. Genomic DNA $(0.1 \mathrm{mg} / \mathrm{ml})$ was prepared in $10 \mathrm{~mm}$ Tris- $\mathrm{HCl}$ ( $\mathrm{pH} 8.0)$ containing $1 \mathrm{~mm}$ EDTA-Na (TE buffer).

\section{PAGE}

SDS-PAGE and native gel electrophoresis were performed on a ready-made $4 \sim 20 \%$ gradient gel (Daiichi Pure Chemicals Co., Ltd.) and 14\% native gel (Funakoshi Pharmaceutical Co., Ltd.), respectively, using a mini-gel apparatus (Daiichi Pure Chemicals Co., Ltd.). For native gel, marker proteins used were phosphorylase $b\left(M_{r} 94,000\right)$, albumin $\left(M_{r} 67,000\right)$, ovalbumin $\left(M_{r} 43,000\right)$ and carbonic anhydrase $\left(M_{r}\right.$ $30,000)$. For SDS-PAGE, marker proteins used were phosphorylase $b\left(M_{r} 94,000\right)$, albumin $\left(M_{r} 67,000\right)$, ovalbumin $\left(M_{r} 43,000\right)$, trypsin inhibitor $\left(M_{r} 20,100\right)$ and $\alpha$-lactoalbumin $\left(M_{r} 14,400\right)$. For $V B$ binding assay with the native gel, after triplicate samples were run on the $14 \%$ native gel, each lane was cut off from the gel. One lane together with a lane of marker proteins was stained for protein with Coomassie brilliant blue G-250. The remaining two lanes were incubated with $91.5 \mathrm{nM}\left[{ }^{3} \mathrm{H}\right] \mathrm{VB}-\mathrm{C}_{7}$ for 1 hour at $25^{\circ} \mathrm{C}$ either in the presence or absence of $0.15 \mathrm{~mm}$ non-labeled VB-C (1,600-fold excess). After the incubation, each gel was washed twice with each $100 \mathrm{ml}$ of Buffer $A$ and sliced into pieces of $0.8 \mathrm{~mm}$ width. Each slice was dissloved in a scintillation vial with a mixture of perchloric acid $(0.2 \mathrm{ml})$ and hydroperoxide $(0.4 \mathrm{ml})$ at $55^{\circ} \mathrm{C}$ for 10 hours. Radioactivity was counted with a liquid scintillator in the presence of $10 \mathrm{ml}$ of Aquasol II (New England Nuclear). The identified band of the VB-C binding protein was cut off from the native gel, extracted by boiling for 10 minutes in $0.5 \mathrm{ml}$ of SDS buffer consisting of $0.0625 \mathrm{M}$ Tris-HCl (pH 6.8), SDS $2 \%$, glycerol 10\%, 2-mercaptoethanol $5 \%$ and bromophenol blue $0.001 \%$, and analyzed by SDS-PAGE as described above.

\section{VB-C Affinity Chromatography}

The phenyl 5PW HPLC fraction was concentrated (binding activity of $2.5 \times 10^{6} \mathrm{dpm}, 0.5 \mathrm{ml}$ ) and applied onto a VB-C affinity column $(0.8 \times 2.5 \mathrm{~cm})$ previously equilibrated with Buffer $\mathrm{B}(\mathrm{pH} 7.0)$ containing $0.1 \mathrm{M} \mathrm{KCl}$. The column was washed with Buffer B containing $0.1 \mathrm{M} \mathrm{KCl}$ and Buffer $\mathrm{B}$ containing $0.3 \mathrm{M}$ $\mathrm{KCl}$ in fractions of $5 \mathrm{ml}$ until no protein was detected in the eluate. Each fraction was assayed for protein and VB binding activity. Then the column was washed with 10 bed volumes of Buffer B ( $\mathrm{pH} 7.5$ ) containing $0.3 \mathrm{M} \mathrm{KCl}$ and VB-C $(10 \mu \mathrm{g} / \mathrm{ml})$ in fractions of $5 \mathrm{ml}$. Several representative fractions were analyzed by $14 \%$ native gel electrophoresis after concentration with Mol cut II (M, 10,000 cut, UFP1 LGC, Nihon Millipore Kogyo K.K.).

\section{Preparation of VB Affinity Resin}

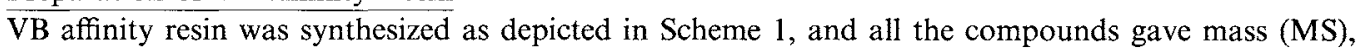
IR and NMR spectra consistent with the structure assigned.

1) 6-Heptenal (1): 1 was synthesized from 7-octene-1,2-diol by oxidative cleavage with $\mathrm{NaIO}_{4}$ as described before ${ }^{14}$.

2) 3,4-trans-3-(Carboxyl)-4-(5'-hexenyl)butanolide (2): To a mixture of succinic anhydride (16.5 g) and 6-heptenal $(6.2 \mathrm{~g})$ in $250 \mathrm{ml}$ pyridine, diazabicyclo[5,4,0]undecene $(25 \mathrm{~g})$ was added dropwise at $0^{\circ} \mathrm{C}$ with stirring. The reaction was continued for 1 hour at $0^{\circ} \mathrm{C}$ and the temperature was raised to $25^{\circ} \mathrm{C}$ and stirred for 3 hours. The reaction was stopped by mixing with cold $3 \mathrm{~N} \mathrm{HCl}$, and the solution was extracted with 
Fig. 2. Second DEAE-Sephacel column chromatography of the VB-C binding protein.

$O$ Protein content, $\bullet$ VB-C binding activity.

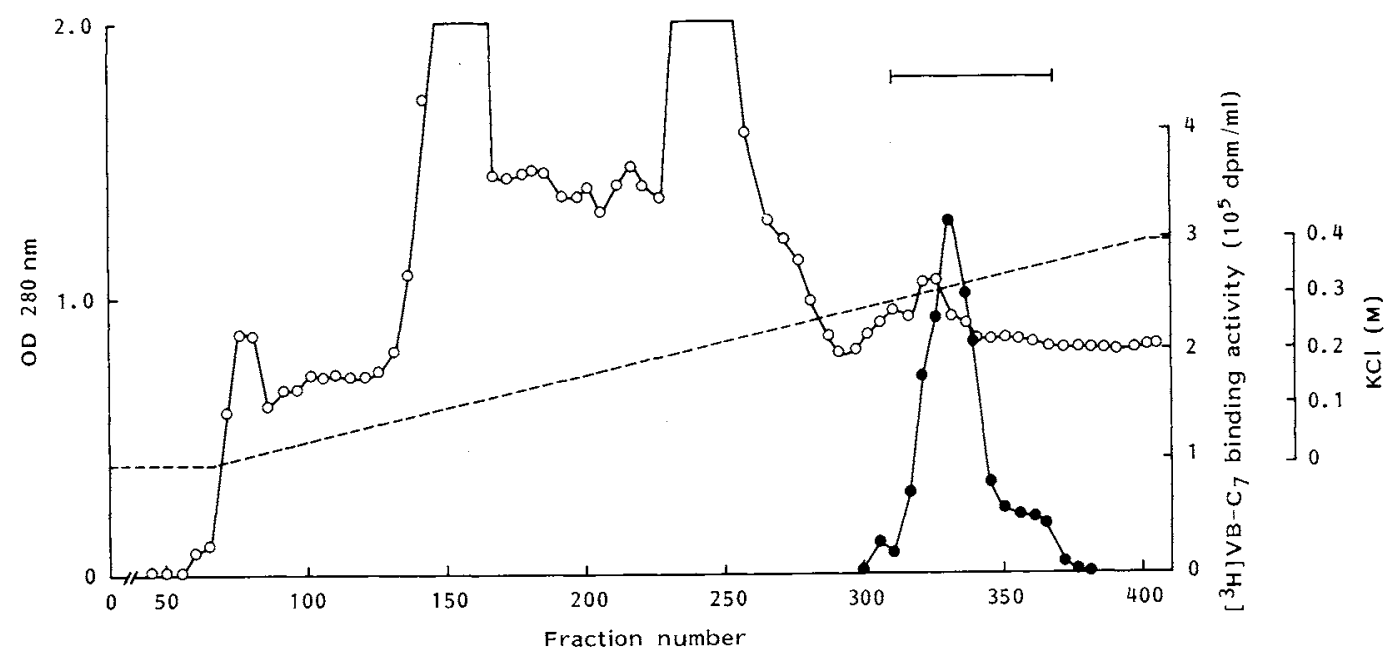

The concentrated solution $(165 \mathrm{ml})$ from Step 3 was applied. Fractions were assayed for protein content and VB-C binding activity. The gradient pattern of $\mathrm{KCl}$ concentration was indicated by a broken line. Fractions 310 through 364 were pooled as indicated by the bar. Fraction size $18 \mathrm{ml}$.

Fig. 3. Sephadex G-100 column chromatography of the VB-C binding protein.

O Protein, $\bullet$ VB binding activity.

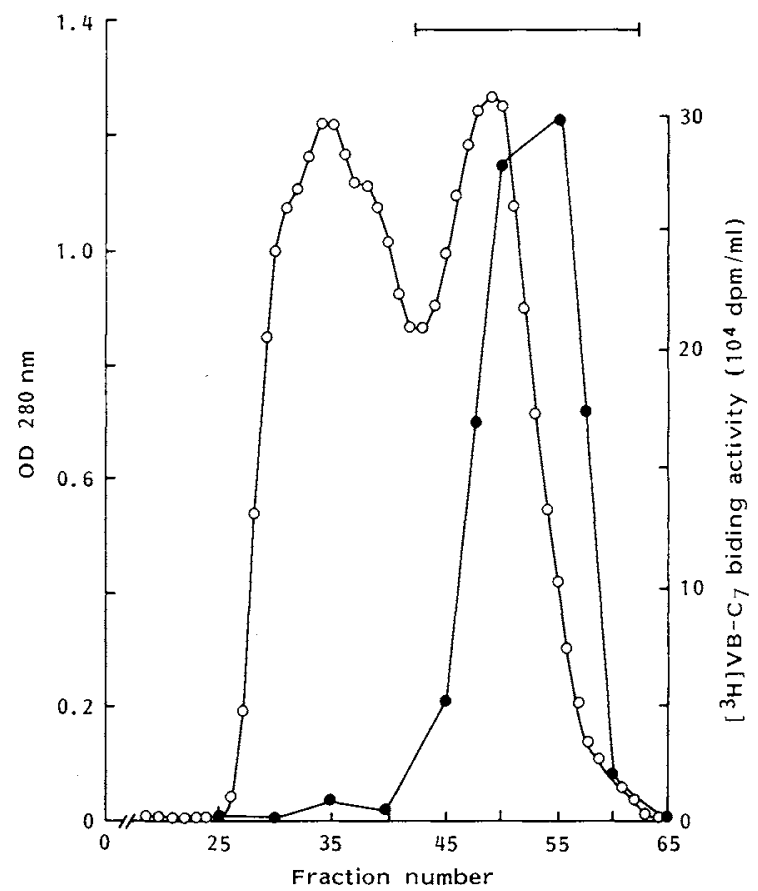

Fractions were assayed for protein and VB binding activity. Fractions 42 through 62 were pooled as indicated by the bar. Fraction size $14 \mathrm{ml}$. 
Fig. 4. Phenyl 5PW HPLC of the VB-C binding protein.

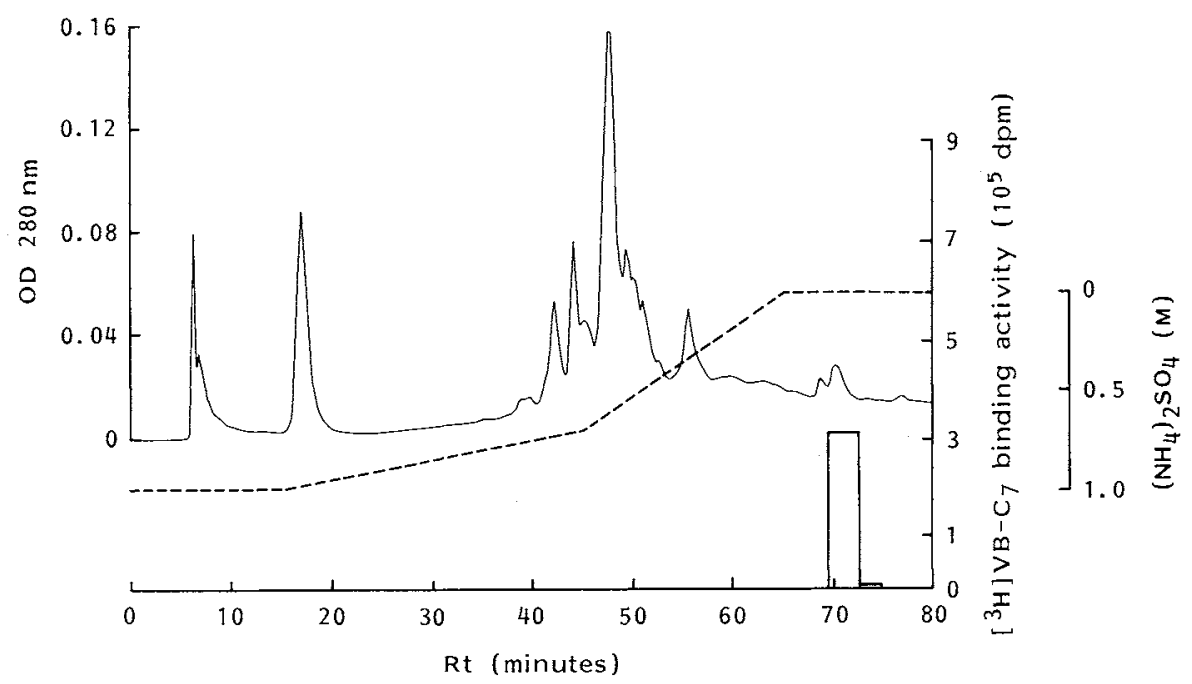

Typical elution profile with $50 \mu$ injection of the concentrate from Step 5 was demonstrated. Gradient profile of ammonium sulfate concentration was indicated by a broken line, and VB binding activity was shown as opened bar. Protein concentration in the eluate was monitored at UV $280 \mathrm{~nm}(-)$.

ether $(150 \mathrm{ml} \times 2)$. The ether layer was washed with water, dried over anhydrous sodium sulfate, and concentrated. The residual oil was washed with hexane $(100 \mathrm{ml})$ and extracted with benzene. The benzene extract was concentrated yielding $10.9 \mathrm{~g}$ of crude oil. The oil was purified on a silica gel $(200 \mathrm{~g})$ column using ether as a solvent, yielding $2.7 \mathrm{~g}$ of 2 ( $23 \%$ yield) and $2.4 \mathrm{~g}$ of $\mathrm{cis}$ isomer ( $20 \%$ yield). EI-MS $\mathrm{m} / \mathrm{z}$ $212(\mathrm{M})^{+}, 194\left(\mathrm{M}-\mathrm{H}_{2} \mathrm{O}\right)^{+}, 176$. IR (film) $\mathrm{cm}^{-1} 3078,2928,2861,1747,1720,1641.2$ methyl ester: ${ }^{1} \mathrm{H}$ NMR $\left(400 \mathrm{MHz}, \mathrm{CDCl}_{3}\right) \delta 5.81(1 \mathrm{H}, \mathrm{m}, 10-\mathrm{H}), 5.03 \sim 4.93(2 \mathrm{H}, \mathrm{m}, 11-\mathrm{H}), 4.64(1 \mathrm{H}, \mathrm{m}, 4-\mathrm{H}), 3.75(3 \mathrm{H}$, $\left.\mathrm{s},-\mathrm{OCH}_{3}\right), 3.45\left(1 \mathrm{H}\right.$, ddd, $J_{3,2 \mathrm{a}}=5.37 \mathrm{~Hz}, J_{3,2 \mathrm{~b}}=8.79 \mathrm{~Hz}$ and $\left.J_{3,4}=7.3 \mathrm{~Hz}, 3-\mathrm{H}\right), 2.88(1 \mathrm{H}$, dd, $J_{2 \mathrm{a}, 3}=5.37 \mathrm{~Hz}$ and $\left.J_{2 \mathrm{a}, 2 \mathrm{~b}}=17.58 \mathrm{~Hz}, 2-\mathrm{Ha}\right), 2.68\left(1 \mathrm{H}, \mathrm{dd}, J_{2 \mathrm{~b}, 3}=8.79 \mathrm{~Hz}\right.$ and $\left.J_{2 \mathrm{~b}, 2 \mathrm{a}}=17.58 \mathrm{~Hz}, 2-\mathrm{Hb}\right), 2.05$ $(2 \mathrm{H}, \mathrm{m}, 9-\mathrm{H}), 1.56(2 \mathrm{H}, \mathrm{m}, 6-\mathrm{H}), 1.42(4 \mathrm{H}, \mathrm{m}, 7-\mathrm{H}, 8-\mathrm{H})$.

3) 3,4-trans-3-(Phenylthiocarbonyl)-4-(5'-hexenyl)butanolide (3): 2 (100 mg) was mixed with carbonyldiimidazole ( $80 \mathrm{mg}, 1.05$ equiv) in $5 \mathrm{ml}$ of dry $\mathrm{CH}_{3} \mathrm{CN}$, and the mixture was stirred for 2 hours at $-10^{\circ} \mathrm{C}$. Thiophenol $\left(55 \mathrm{mg}, 1.05\right.$ equiv) was added and the reaction continued for 2 hours at $-10^{\circ} \mathrm{C}$. After evaporation to remove $\mathrm{CH}_{3} \mathrm{CN}$, the residue was extracted with hexane $(30 \mathrm{ml}$ each, 5 times), and the hexane layer was dried over anhydrous sodium sulfate, and evaporated. The resulting oil $(110 \mathrm{mg})$ was purified on a silica gel $(8 \mathrm{~g})$ column using hexane - EtOAc $(9: 1)$, yielding $3(72 \mathrm{mg}$, yield $50 \%)$. EI-MS $\mathrm{m} / \mathrm{z}$ $304(\mathrm{M})^{+}, 276,247,195 .{ }^{1} \mathrm{H}$ NMR $\left(600 \mathrm{MHz}, \mathrm{CDCl}_{3}\right) \delta 7.44 \sim 7.30(5 \mathrm{H}, \mathrm{m}$, phenyl), $5.78(1 \mathrm{H}, \mathrm{m}, 10-\mathrm{H})$, $5.00 \sim 4.93(2 \mathrm{H}, \mathrm{m}, 11-\mathrm{H}), 4.69(1 \mathrm{H}, \mathrm{m}, 4-\mathrm{H}), 3.75\left(1 \mathrm{H}, \mathrm{td}, J_{3,2 \mathrm{a}}=6.1 \mathrm{~Hz}\right.$ and $\left.J_{3,2 \mathrm{~b}}=8.4 \mathrm{~Hz}, 3-\mathrm{H}\right), 2.91$ $\left(1 \mathrm{H}, \mathrm{dd}, J_{2 \mathrm{a}, 3}=6.4 \mathrm{~Hz}\right.$ and $\left.J_{2 \mathrm{a}, 2 \mathrm{~b}}=17.9 \mathrm{~Hz}, 2-\mathrm{Ha}\right), 2.67\left(1 \mathrm{H}, \mathrm{dd}, J_{2 \mathrm{~b}, 3}=8.4 \mathrm{~Hz}\right.$ and $\left.J_{2 \mathrm{~b}, 2 \mathrm{a}}=17.9 \mathrm{~Hz}, 2-\mathrm{Hb}\right)$, $2.05(2 \mathrm{H}, \mathrm{m}, 9-\mathrm{H}), 1.68(2 \mathrm{H}, \mathrm{m}, 6-\mathrm{H}), 1.56 \sim 1.43(4 \mathrm{H}, \mathrm{m}, 7-\mathrm{H}, 8-\mathrm{H}) . \mathrm{IR}$ (film) $\mathrm{cm}^{-1} 3060,2920,2850$, $1785,1705,1640$.

4) 3,4-trans-3-(Hydroxymethyl)-4-(5'-hexenyl)butanolide (4): To a solution of $\mathrm{NaBH}_{4}$ (10 mg) in a mixture of $9 \mathrm{ml}$ of THF and $1 \mathrm{ml}$ of water, $3\left(100 \mathrm{ml}\right.$ in $1 \mathrm{ml}$ of THF) was added dropwise at $-10^{\circ} \mathrm{C}$ with stirring. After stirring for 6 hours, AcOH $(1 \mathrm{ml})$ was added, and the solution was evaporated to remove THF. Water was added to the residue, and the mixture was extracted with EtOAc. The EtOAc layer was dried over anhydrous sodium sulfate, and evaporated. The resulting oil $(173 \mathrm{mg})$ was purified on a silica gel $(8.5 \mathrm{~g})$ with ether as solvent, yielding $45 \mathrm{mg}$ of 4 (yield $65 \%$ ). EI-MS $m / z 199(\mathrm{M}+\mathrm{H})^{+}, 180\left(\mathrm{M}-\mathrm{H}_{2} \mathrm{O}\right)^{+}$. IR (film) $\mathrm{cm}^{-1} 3430,3050,2920,2850,1765,1640 .{ }^{1} \mathrm{H} \mathrm{NMR}\left(600 \mathrm{MHz}, \mathrm{CDCl}_{3}\right) \delta 5.76(1 \mathrm{H}, \mathrm{m}, 10-\mathrm{H})$, $4.94(2 \mathrm{H}, \mathrm{m}, 11-\mathrm{H}), 4.35\left(1 \mathrm{H}, \mathrm{td}, J_{4,3}=8.2 \mathrm{~Hz}, 4-\mathrm{H}\right), 3.66\left(2 \mathrm{H}, \mathrm{d}, J_{5,3}=5.6 \mathrm{~Hz}, 5-\mathrm{H}\right), 2.62(1 \mathrm{H}$, dd, $J_{2 \mathrm{a}, 3}=9.0 \mathrm{~Hz}$ and $\left.J_{2 \mathrm{a}, 2 \mathrm{~b}}=18.2 \mathrm{~Hz}, 2-\mathrm{Ha}\right), 2.43\left(1 \mathrm{H}, \mathrm{dd}, J_{2 \mathrm{~b}, 3}=7.2 \mathrm{~Hz}\right.$, and $\left.J_{2 \mathrm{~b}, 2 \mathrm{a}}=18.2 \mathrm{~Hz}, 2-\mathrm{Hb}\right), 2.35$ $(1 \mathrm{H}, \mathrm{m}, 3-\mathrm{H}), 2.05(2 \mathrm{H}, \mathrm{m}, 9-\mathrm{H}), 1.66(2 \mathrm{H}, \mathrm{m}, 6-\mathrm{H}), 1.51 \sim 1.41(4 \mathrm{H}, \mathrm{m}, 7-\mathrm{H}, 8-\mathrm{H})$. 
Scheme 1. Synthetic route of the VB-C affinity resin.

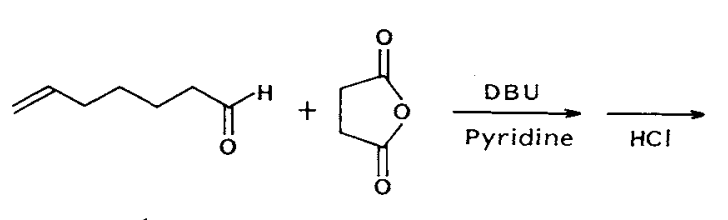

1<smiles>C=CCCCC1C2CC(C(=O)O)C(C2)C1O</smiles>

2<smiles>C=CCCCOC1OC(=O)CC1C(=O)Sc1ccccc1</smiles>

3

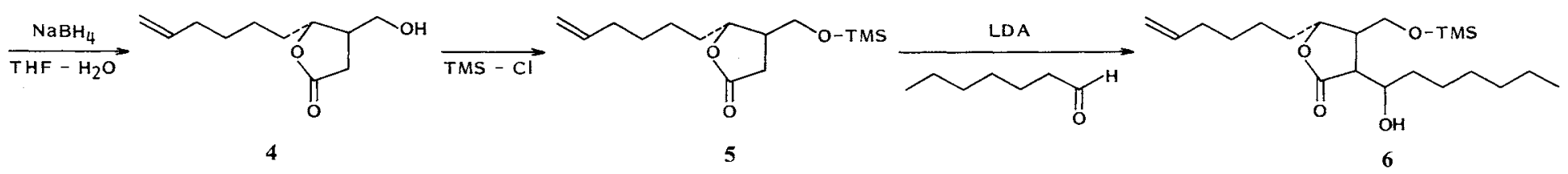

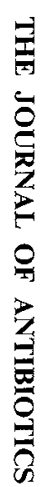

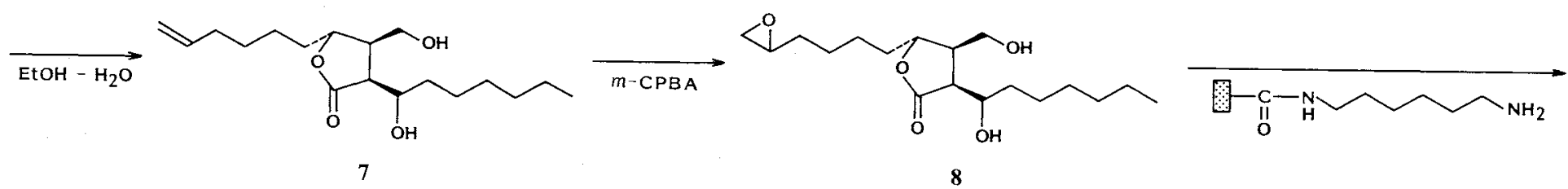


5) 2,3-cis-3,4-trans-2-(1'-Hydroxyheptyl)-3-(hydroxymethyl)-4-(5'-hexenyl)butanolide (7): 4 was trimethylsilylated with trimethylsilyl chloride and hexamethyldisilazane to yield $\mathbf{5}$. $\mathbf{6}$ was synthesized by aldol condensation in the presence of lithium diisopropylamine (LDA) from $\mathbf{5}$ and 1-heptanal essentially as described before ${ }^{10)}$, and converted into 7 by refluxing in $\mathrm{EtOH}-\mathrm{H}_{2} \mathrm{O}(4: 1)$. Yield from $\mathbf{4}$ to 7: 13.7\%. 2,3-trans-Isomer was obtained with $52.1 \%$ yield. EI-MS $m / z 312(\mathrm{M})^{+}, 294\left(\mathrm{M}-\mathrm{H}_{2} \mathrm{O}\right)^{+}$. IR (film) $\mathrm{cm}^{-1}$ $3400,3060,2930,2850,1745,1640 .{ }^{1} \mathrm{H}$ NMR $\left(600 \mathrm{MHz}, \mathrm{CDCl}_{3}\right) \delta 5.77(1 \mathrm{H}, \mathrm{m}, 17-\mathrm{H}), 4.96(2 \mathrm{H}, \mathrm{m}$, $18-\mathrm{H}), 4.23\left(1 \mathrm{H}, \mathrm{td}, J_{4,3}=8.1 \mathrm{~Hz}, 4-\mathrm{H}\right), 4.04(1 \mathrm{H}, \mathrm{m}, 6-\mathrm{H}), 3.69\left(2 \mathrm{H}, \mathrm{d}, J_{5,3}=5.0 \mathrm{~Hz}, 5-\mathrm{H}\right), 2.68(1 \mathrm{H}, \mathrm{dd}$, $J_{2,3}=9.2 \mathrm{~Hz}$ and $\left.J_{2,6}=4.8 \mathrm{~Hz}, 2-\mathrm{H}\right), 2.39(1 \mathrm{H}, \mathrm{m}, 3-\mathrm{H}), 2.04(2 \mathrm{H}, \mathrm{m}, 16-\mathrm{H}), 1.75 \sim 1.27(16 \mathrm{H}, \mathrm{m}), 0.87$ $(3 \mathrm{H}, \mathrm{t}, J=7.0 \mathrm{~Hz}, 12-\mathrm{H})$.

6) 2,3-cis-3,4-trans-2-(1'-Hydroxyheptyl)-3-(hydroxymethyl)-4-(5',6'-epoxyhexyl)butanolide (8): 7 ( $30 \mathrm{mg}$ ) was dissolved in $5 \mathrm{ml}$ of dichloromethane, and $m$-chloroperbenzoic acid (22.6 $\mathrm{mg}, 1.1$ equiv) was added with stirring. After reaction for 5 hours, reaction mixture was washed successively with $10 \% \mathrm{NaHCO}_{3}$ and water, and the dichloromethane layer was dried over anhydrous sodium sulfate. After evaporation, the residual oil was purified on a silica gel column using ether as solvent, yielding $14 \mathrm{mg}$ of 8 . CI-MS $\mathrm{m} / \mathrm{z} 329$ $(\mathrm{M}+\mathrm{H})^{+}, 311\left(\mathrm{M}-\mathrm{H}_{2} \mathrm{O}+1\right)^{+}, 293$. IR (film) $\mathrm{cm}^{-1} 3400,2920,2850,1740 .{ }^{1} \mathrm{H} \mathrm{NMR}\left(600 \mathrm{MHz}, \mathrm{CDCl}_{3}\right)$ $\delta 4.26\left(1 \mathrm{H}, \mathrm{td}, J_{4,3}=8.1 \mathrm{~Hz}, 4-\mathrm{H}\right), 4.07(1 \mathrm{H}, \mathrm{m}, 6-\mathrm{H}), 3.71(2 \mathrm{H}, \mathrm{m}, 5-\mathrm{H}), 2.90(1 \mathrm{H}, \mathrm{m}, 17-\mathrm{H}), 2.74(2 \mathrm{H}$, $\mathrm{t}, J=4.4 \mathrm{~Hz}, 18-\mathrm{H}), 2.67\left(1 \mathrm{H}, \mathrm{dd}, J_{2,6}=3.95 \mathrm{~Hz}, J_{2,3}=9.08 \mathrm{~Hz}, 2-\mathrm{H}\right), 2.46(2 \mathrm{H}, \mathrm{m}, 16-\mathrm{H}), 2.42(1 \mathrm{H}, \mathrm{m}$, $3-\mathrm{H}), 1.75 \sim 1.27(16 \mathrm{H}, \mathrm{m}), 0.87(3 \mathrm{H}, \mathrm{t}, J=6.9 \mathrm{~Hz}, 12-\mathrm{H})$.

7) Coupling of 8 with $\omega$-Aminohexyl Sepharose 4B: $\omega$-Aminohexyl Sepharose 4B was prepared from Sepharose $4 \mathrm{~B}$ and hexamethylenediamine according to the method of CUATrECASA ${ }^{20}$. $\omega$-Aminohexyl Sepharose 4B ( $20 \mathrm{ml}$-packed volume, $5.34 \mu \mathrm{mol}-\mathrm{NH}_{2} / \mathrm{ml}$-packed) was suspended in $20 \mathrm{ml}$ of $50 \%$ dioxane in $0.1 \mathrm{M}$ sodium carbonate buffer $(\mathrm{pH} 9.0)$, and $8(10 \mathrm{mg})$ in $1 \mathrm{ml}$ of the same solution was added with mild stirring at room temperature. The reaction continued for 20 hours. After the reaction, the resin was collected by suction filtration, and throughly washed with each $500 \mathrm{ml}$ of $50 \%$ aqueous dioxane, $0.1 \mathrm{M}$ sodium carbonate buffer ( $\mathrm{pH} 9.0$ ) containing $0.5 \mathrm{M} \mathrm{NaCl}$, and $0.1 \mathrm{M}$ sodium acetate buffer ( $\mathrm{pH} 4.0$ ) containing $0.5 \mathrm{M} \mathrm{NaCl}$. After the washing, the resin was throughly equilibrated with Buffer B containing $0.1 \mathrm{M} \mathrm{KCl}$.

Estimation of MW of the VB-C Binding Protein by Molecular Sieve HPLC

Concentrated Sephadex G-100 fraction $(50 \mu \mathrm{l})$ was injected into the molecular sieve column (TSK $\mathrm{G} 2000 \mathrm{SW}_{\mathrm{XL}}, \mathrm{M}_{\mathrm{r}}<160,000$, Tosoh Manufacturing Co., Ltd.), and eluted with Buffer B containing $0.1 \mathrm{M}$ $\mathrm{KCl}$ or Buffer $\mathrm{B}$ containing $0.5 \mathrm{M} \mathrm{KCl}$ at a flow rate of $0.8 \mathrm{ml} /$ minute. Fractions were collected every 15 seconds, and $100 \mu \mathrm{l}$ of each fraction was assayed for VB binding activity to detemine the elution position of the VB-C binding protein as indicated by an arrow. Calibration curve was obtained from the Rt's of marker proteins under each conditions: 1) Glutamate dehydrogenase $\left(M_{r} 290,000\right)$, 2) lactate dehydrogenase $\left(M_{r} 142,000\right)$, 3) yeast enolase $\left(M_{r} 67,000\right)$, 4) yeast adenylate kinase $\left(M_{r} 32,000\right)$, 5) cytochrome $C\left(M_{r}\right.$ $12,400)$.

\section{Results and Discussion}

\section{Binding Assay with $\left[{ }^{3} \mathrm{H}\right] \mathrm{VB}-\mathrm{C}_{7}$}

In our previous report ${ }^{14)}$ which established the existence of VB-C specific binding protein in the crude extract from S. virginiae, we used equilibrium dialysis for measuring the binding activity. Although the equilibrium dialysis can be considered as a basic and precise method for measuring any ligand binding, it is too troublesome and time-consuming for dealing with many samples, such as during purification of the VB-C binding protein. Therefore, before starting the purification, we sought a rapid assay method for measuring the VB-C binding activity. After surveying several methods, we found that precipitation with ammonium sulfate as described in Materials and Methods served as quick and easy method for the assay of VB-C binding. Binding assay by equilibrium dialysis usually gave $2 \sim 3$-fold lower activity due to the inactivation of the binding protein during the long dialysis period. Adsorption on hydroxyapatite, serveral ion-exchange resins or active charcoal in the presence of dextran ${ }^{21)}$ were found unsuitable either due to 
Fig. 5. Time course of $\left[{ }^{3} \mathrm{H}\right]$ VB- $\mathrm{C}_{7}$ binding to the binding protein and dependence of $\left[{ }^{3} \mathrm{H}\right] \mathrm{VB}-\mathrm{C}_{7}$ binding on the amount of binding protein.

(A)

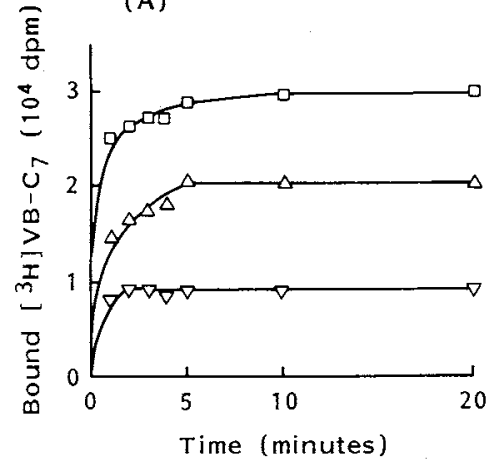

(B)

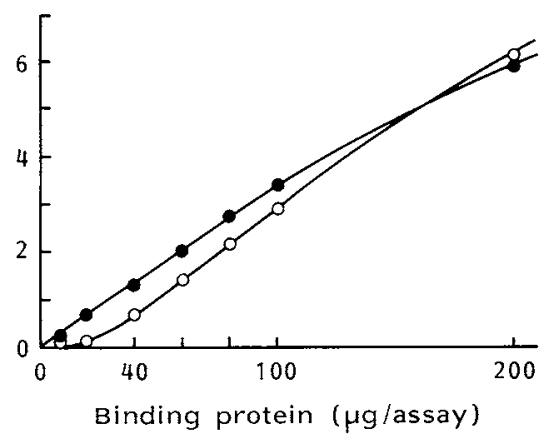

(A) Partially purified binding protein (Sephadex G-100 fraction, $50 \mu \mathrm{g}$ per assay) were incubated with $69.6 \mathrm{nM}\left[{ }^{3} \mathrm{H}\right] \mathrm{VB}-\mathrm{C}_{7}$ for the indicated time in the presence and absence of $0.125 \mathrm{~mm}$ non-labeled VB-C. $\square$ Total, $\triangle$ specific, $\nabla$ nonspecific. (B) Incubation time was fixed for 20 minutes and precipitation with ammonium sulfate was done in the absence $(O)$ and presence of $500 \mu \mathrm{g}$ of bovine blood hemoglobin (๑).

weak binding of the binding protein or high non-specific binding of $\left[{ }^{3} \mathrm{H}\right] \mathrm{VB}-\mathrm{C}_{7}$ (data not shown).

With this new method it became possible to follow the time course of the $\left[{ }^{3} \mathrm{H}\right] \mathrm{VB}-\mathrm{C}_{7}$ binding to the binding protein (Fig. 5A). As evident from the figure, the binding was very rapid, reached a plateau at around 5 minutes, and remained constant until 20 minutes. Longer incubation caused a gradual decrease of the specific binding (16\% decrease at 60 minutes incubation). Therefore, we selected the incubation time of 20 minutes for the binding assay, which was also critically affected by the total protein concentration during precipitation of the binding protein by ammonium sulfate (Fig. 5B). Incomplete precipitation of the binding protein, resulting in underestimation of the binding activity, was overcome by including hemoglobin $(0.5 \mathrm{mg}$ per assay) during the precipitation.

\section{Intracellular Localization of the VB-C Binding Protein}

The specific binding was observed almost exclusively in the soluble fraction $(>95 \%)$ when the extract was prepared in Buffer B. Furthermore, the specific binding activity did not translocate into the membrane fraction when growing cells were treated with $\left[{ }^{3} \mathrm{H}\right] \mathrm{VB}-\mathrm{C}_{7}$ for several hours at $28^{\circ} \mathrm{C}$ before preparing the extract (data not shown). Therefore, the VB-C binding protein seemed to be present in the soluble but not in the membrane fraction. A similar conclusion was also drawn for A-factor binding protein from $S$. griseus $^{22)}$.

\section{Ligand Specificity of the VB-C Binding Protein}

In our previous report ${ }^{14)}$, we demonstrated that the VB-C binding protein has a high preference for cis VB-C as ligand (cis VB-C >trans VB-C $\gg \mathrm{A}$-factor type), which correlates well with the effectiveness in inducing virginiamycin production. In $S$. virginiae, we have found five different VBs (VB-A, B, C, D and E: Fig. 1$)^{9,10)}$. To know whether the VB-C binding protein can bind other VBs as well as VB-C, we investigated their effectiveness as a competitive ligand during the binding assay (Table 1). As expected, optically active VB-A and VB-D showed the same level of effectiveness as that of cis VB-C, indicating that they can bind to the VB-C binding protein with similar affinity. For VB-B, there are two possible enantiomers with respect to the configuration at C-9, which we have not yet determined. Of the two isomers, that with the $S$ 
Table 1. Ligand specificity of the VB-C binding protein toward several VBs.

\begin{tabular}{|c|c|c|c|c|c|c|c|c|c|c|}
\hline & \multicolumn{10}{|c|}{ Bound $\left[{ }^{3} \mathrm{H}\right]$ VB- $\mathrm{C}_{7}$} \\
\hline$\pi$ & \multicolumn{2}{|c|}{$\begin{array}{l}100 \text {-fold } \\
\text { molar excess }\end{array}$} & \multicolumn{2}{|c|}{$\begin{array}{c}250 \text {-fold } \\
\text { molar excess }\end{array}$} & \multicolumn{2}{|c|}{$\begin{array}{c}\text { 500-fold } \\
\text { molar excess }\end{array}$} & \multicolumn{2}{|c|}{$\begin{array}{l}\text { 750-fold } \\
\text { molar excess }\end{array}$} & \multicolumn{2}{|c|}{$\begin{array}{c}1,000 \text {-fold } \\
\text { molar excess }\end{array}$} \\
\hline Non-labeled VBs & $10^{4} \mathrm{dpm}$ & $\%$ & $10^{4} \mathrm{dpm}$ & $\%$ & $10^{4} \mathrm{dpm}$ & $\%$ & $10^{4} \mathrm{dpm}$ & $\%$ & $10^{4} \mathrm{dpm}$ & $\%$ \\
\hline VB-A $(\mathrm{R}=$ & 0.61 & 30.3 & 0.62 & 30.5 & 0.60 & 29.8 & 0.63 & 31.1 & 0.56 & 27.9 \\
\hline VB-B' $(R=$ & 0.89 & 44.2 & 0.72 & 35.6 & 0.59 & 29.2 & 0.63 & 31.1 & 0.59 & 29.2 \\
\hline VB-B (F & 0.68 & 33.5 & 0.64 & 31.8 & 0.64 & 31.8 & 0.53 & 26.5 & 0.61 & 30.2 \\
\hline $\begin{array}{l}2,3-c i s \\
\text { VB-C (R= }\end{array}$ & 0.64 & 31.8 & 0.64 & 31.8 & 0.57 & 28.4 & 0.58 & 28.7 & 0.57 & 28.4 \\
\hline 2,3-trans VB-C & 1.19 & 58.6 & 0.94 & 46.5 & 0.82 & 40.8 & 0.78 & 38.5 & 0.69 & 34.2 \\
\hline VB-D $(R=$ & 0.63 & 31.3 & 0.56 & 27.9 & 0.52 & 25.8 & 0.52 & 25.8 & 0.46 & 22.6 \\
\hline \multirow{3}{*}{$\begin{array}{l}\text { Control } \\
(-V B s)\end{array}$} & \multicolumn{4}{|c|}{ Bound $\left[{ }^{3} \mathrm{H}\right] \mathrm{VB}-\mathrm{C}_{7}$} & & & & & & \\
\hline & \multicolumn{2}{|c|}{$10^{4} \mathrm{dpm}$} & \multicolumn{2}{|l|}{$\%$} & & & & & & \\
\hline & \multicolumn{2}{|c|}{2.02} & \multicolumn{2}{|l|}{100} & & & & & & \\
\hline
\end{tabular}

Concentrated Sephadex G-100 fraction was assayed in the presence and absence of non-labeled synthetic VBs. 1,000 -fold molar excess equals $69.6 \mu \mathrm{m}$ of cold VBs.

Table 2. Purification of VB-C binding protein from Streptomyces virginiae.

\begin{tabular}{|c|c|c|c|c|c|}
\hline $\begin{array}{c}\text { Purification } \\
\text { step }\end{array}$ & $\begin{array}{l}\text { Total } \\
\text { protein } \\
(\mathrm{mg})\end{array}$ & $\begin{array}{l}\text { Total } \\
\text { activity } \\
\text { (dpm) }\end{array}$ & $\begin{array}{l}\text { Specific } \\
\text { activity } \\
\text { (dpm/mg) }\end{array}$ & $\begin{array}{c}\text { Purification } \\
\text { (-fold) }\end{array}$ & $\begin{array}{l}\text { Yield } \\
(\%)\end{array}$ \\
\hline Crude protein & $30,927.6$ & $1.31 \times 10^{9}$ & $4.2 \times 10^{4}$ & 1 & 100 \\
\hline $\begin{array}{l}\left(\mathrm{NH}_{4}\right)_{2} \mathrm{SO}_{4} \\
\text { fractionation } \\
(30 \sim 50 \%)\end{array}$ & $12,735.5$ & $6.66 \times 10^{8}$ & $5.2 \times 10^{4}$ & 1.2 & 50.6 \\
\hline Ist DEAE-Sephacel & $6,476.2$ & $3.60 \times 10^{8}$ & $5.5 \times 10^{4}$ & 1.3 & 27.4 \\
\hline 2nd DEAE-Sephacel & 531.7 & $2.10 \times 10^{8}$ & $3.9 \times 10^{5}$ & 9.2 & 15.9 \\
\hline Sephadex G-100 & 212.1 & $1.70 \times 10^{8}$ & $8.0 \times 10^{5}$ & 18.8 & 12.9 \\
\hline Pheny 5PW HPLC & 4.3 & $1.30 \times 10^{8}$ & $3.0 \times 10^{7}$ & 710 & 9.9 \\
\hline
\end{tabular}

configuration showed similar affinity as cis VB-C while the $(R)$-isomer (VB-B') was as ineffective as trans VB-C. Therefore, natural VB-B seemed to have $S$ configuration at C-9.

From these results, it can be concluded that the VB-C binding protein accepts all the natural VBs and may function as the common binding protein in $S$. virginiae.

\section{Purification of the VB-C Binding Protein}

The VB-C binding protein, present at about $30 \sim 40$ molecules per genome DNA ${ }^{14)}$, is only a minor component of cellular proteins, and a procedure to purify the binding protein was developed. The purification starting from $500 \mathrm{~g}$ of wet mycelia is summarized in Table 2. After 5 steps of purification, during which hydrophobic HPLC was very effective, we obtained $4.3 \mathrm{mg}$ of partially purified VB-C binding protein with $10 \%$ yield. To check the purity of this fraction, we ran $14 \%$ native PAGE (Fig. 6, 
Fig. 6. Native polyacrylamide gel electrophoresis of the VB-C binding protein (left) and VB-C binding analysis of the gel (right)

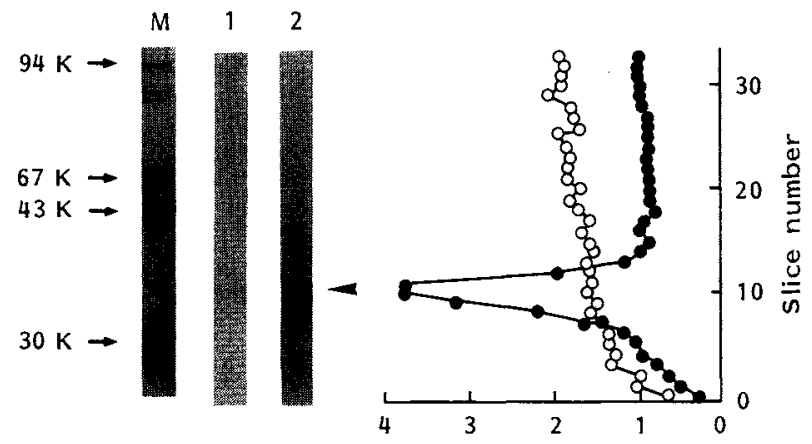

Bound $\left[{ }^{3} \mathrm{H}\right] \vee \mathrm{B}-\mathrm{C}_{7}\left(10^{3} \mathrm{dpm} / \mathrm{slice}\right)$

VB-C eluted sample from VB-C affinity chromatography (track 1), concentrated sample from phenyl 5PW HPLC (track 2) and marker proteins (track M) were run on 14\% native gel and stained with Coomasie brilliant blue G-250. VB binding analysis on the gel was done in the presence (•) and absence $(O)$ of non-labeled VB-C. The band corresponding to the VB-C binding protein was indicated by an arrow.

lane 2) and several bands centering at $M_{r}$ of 36,000 were observed. To determine the precise position of the binding protein, the gel was incubated with $\left[{ }^{3} \mathrm{H}\right] \mathrm{VB}-\mathrm{C}_{7}$ in the presence and absence of non-labeled VB-C, sliced into $0.8 \mathrm{~mm}$ segments, and the radioactivity in each slice was counted as described in Materials and Methods (Fig. 6, right). The pattern of binding activity indicated that the band in track 2 indicated by an arrow should be the VB-C binding protein. To confirm this, we considered that affinity chromatography using a VB-C analog as affinity ligand should be most suitable. The affinity ligand, synthesized as depicted in Scheme 1, had a spacer group at C-4. In the structure of VB-C, the C-3 hydroxymethyl group and the $\mathrm{C}-2$ side chain including the C-6-hydroxy group have been established as essential for the activity: Modification or deletion of them caused $100 \sim 1,000$-fold decrease in the effectiveness as the inducer for virginiamycin production ${ }^{17)}$. Therefore, in designing the affinity ligand, only position $\mathrm{C}-4$ remained as a candidate for attaching the spacer group. Fortunately, compound 7 exhibited almost the same degree of competition as VB-C against $\left[{ }^{3} \mathrm{H}\right] \mathrm{VB}-\mathrm{C}_{7}$ in the binding assay (data not shown), and therefore, high binding ability of the affinity resin toward the binding protein was expected. When the active fraction from phenyl 5PW HPLC (binding activity of $2.5 \times 10^{6} \mathrm{dpm}$ ) was applied to the VB affinity column, all the activity was retained on the column and was not eluted during successive washes with Buffer $B$ containing $0.1 \mathrm{M} \mathrm{KCl}$ or $0.3 \mathrm{M} \mathrm{KCl}$. However, the same protein band of $\mathrm{M}_{\mathrm{r}} 36,000$ as in track 2 was specifically eluted with Buffer B containing $0.3 \mathrm{M} \mathrm{KCl}$ plus VB-C at $10 \mu \mathrm{g} / \mathrm{ml}$ (Fig. 6, track 1). Unfortunately, binding activity in this fraction could not be measured due to the complete inhibition of $\left[{ }^{3} \mathrm{H}\right]$ VB- $\mathrm{C}_{7}$ binding by already bound cold VB-C used as eluent. However, the specific elution of the band from the affinity column by VB-C suggests that it is actually the VB-C binding protein. To know the MW of the binding protein, we carefully cut off the band from the native gel, extracted with SDS buffer and analyzed on $4 \sim 20 \%$ SDS-PAGE (Fig. 7). The extracted protein showed a single band with $M_{r}$ of 35,800 as shown in Fig. 7B. In our previous paper, we estimated the MW of the VB-C binding protein to be about 20,000 from the retention time on molecular sieve HPLC using a TSK G2000 $\mathrm{SW}_{\mathrm{XL}}$ column. However, the rather hydrophobic nature of the binding protein, as evident from its tight binding to phenyl 
Fig. 7. MW determination of the purified VB-C binding protein on SDS-PAGE under reduced conditions.

(A)

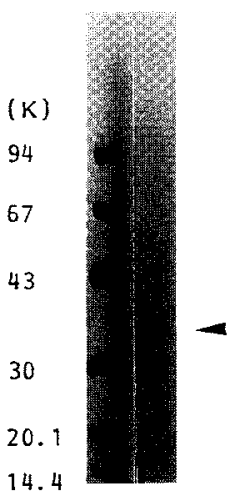

(B)

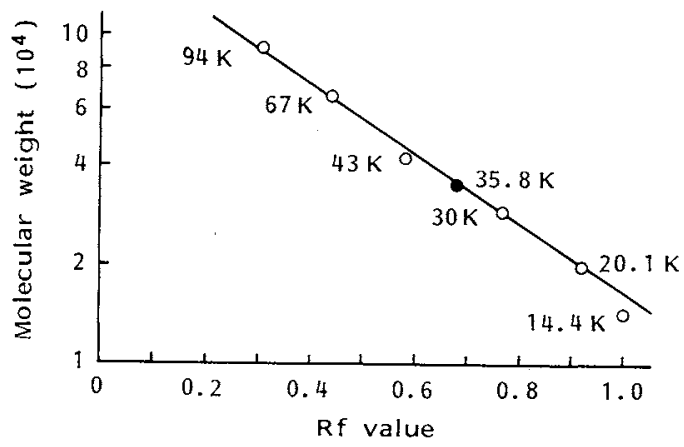

(A) The band indicated by an arrow in Fig. 5 was run on a $4 \sim 20 \%$-gradient gel (right lane) together with marker proteins (left lane), and stained with Coomassie brilliant blue G-250. The position of the VB-C binding protein was indicated by an arrow. (B) A plot of $\log \mathrm{M}_{\mathrm{r}}$ against the migration of marker proteins $(O)$ and VB-C binding protein $(\bullet)$.

Fig. 8. Estimation of MW of the VB-C binding protein by molecular sieve HPLC eluted with Buffer B containing $0.1 \mathrm{M} \mathrm{KCl}$ and Buffer $\mathrm{B}$ containing $0.5 \mathrm{M} \mathrm{KCl}$.

(A) $0.1 \mathrm{M} \mathrm{KCl}$, (B) $0.5 \mathrm{M} \mathrm{KCl}$.

(A)

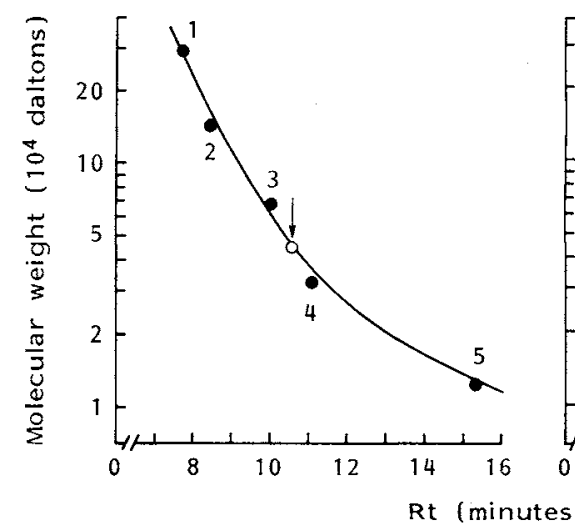

(B)

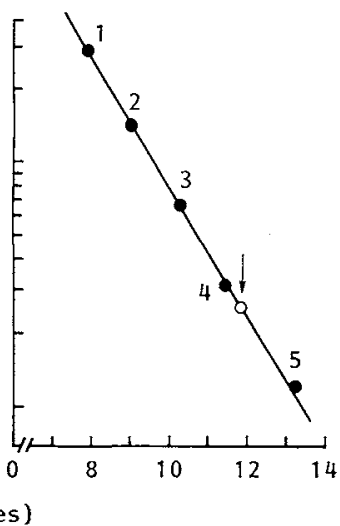

5PW column, may have influenced the retention time on the molecular sieve HPLC. Thus, a clear difference in the retention time under high and low ionic strength was observed (Fig. 8). The VB-C binding protein appeared at $\mathrm{M}_{\mathrm{r}}$ of 26,000 in the presence of $0.5 \mathrm{M} \mathrm{KCl}$ (Fig. $8 \mathrm{~B}$ ) but in the presence of $0.1 \mathrm{M} \mathrm{KCl}$ it appeared earlier at $M_{r}$ of 44,000 (Fig. 8A), suggesting that hydrophobic interaction between the resin and the binding protein under high ionic strength resulted in the underestimation of the MW. We could not estimate the $\mathrm{MW}$ of the binding protein at lower ionic strength because at $\mathrm{KCl}$ concentration lower than $0.1 \mathrm{M}$ ionic interaction becomes dominant and even standard proteins were not separated well. Although we can not exclude the possibility that after elution from the column the binding protein forms aggregates of higher MW during the binding assay, its behavior during molecular sieve HPLC at low ionic strength (apparent $M_{r}$ about 44,000) and during SDS-PAGE (apparent $M_{r} 35,800$ ) are consistent with the monomeric nature of the VB-C binding protein. This low MW clearly distinguishes the VB-C binding protein from a receptor 
Table 3. Effect of genomic DNA from Streptomyces virginiae on the VB-C binding activity.

\begin{tabular}{|c|c|c|c|c|c|}
\hline \multicolumn{4}{|c|}{ Procedure for binding activity measurement } & $\begin{array}{c}\text { Specific }\left[{ }^{3} \mathrm{H}\right] V B-\mathrm{C}_{7} \text { bound } \\
\left(10^{3} \mathrm{dpm}\right)\end{array}$ & $\begin{array}{c}\text { Relative activity } \\
(\%)\end{array}$ \\
\hline 1) $\mathrm{BP}+\mathrm{DNA}$ & $\longrightarrow$ & $\pm \mathrm{VB}_{-} \mathrm{C}_{6}$ & $\stackrel{*}{*} \mathrm{VB}_{-} \mathrm{C}_{7}$ & 14.32 & 61 \\
\hline 2) $\mathrm{BP}-\mathrm{DNA}$ & $\longrightarrow$ & $\pm \mathrm{VB}^{-\mathrm{C}_{6}} \longrightarrow$ & $\stackrel{*}{*}{\mathrm{VB}-\mathrm{C}_{7}}^{\longrightarrow}$ & 23.49 & 100 \\
\hline 3) $\mathrm{BP}$ & $\stackrel{\mathrm{VB}-\mathrm{C}_{6}}{\longrightarrow}$ & $+{ }^{*} \mathrm{VB}_{-} \mathrm{C}_{7}$ & $\stackrel{+\mathrm{DNA}}{\longrightarrow}$ & 20.91 & 89 \\
\hline 4) + DNA & $\stackrel{\mathrm{VB}-\mathrm{C}_{6}}{\longrightarrow}$ & $+{ }^{*} \mathrm{VB}-\mathrm{C}_{7}$ & $+\mathrm{BP}$ & 23.38 & 99.5 \\
\hline 5) - DNA & $\pm \mathrm{VB}^{-C_{6}} \longrightarrow$ & $+{ }^{*} \mathrm{VB}^{-C_{7}}$ & $+\mathrm{BP}$ & 23.42 & 99.7 \\
\hline
\end{tabular}

Ten $\mu$ of the DNA solution ( + DNA) or TE buffer alone ( - DNA) was added. Incubation indicated by each arrow was done for 20 minutes at $25^{\circ} \mathrm{C}$.

BP: Binding protein, $\pm \mathrm{VB}-\mathrm{C}_{6}$ : plus or minus $0.125 \mathrm{~mm}$ non-labeled $\mathrm{VB}-\mathrm{C},{ }^{*} \mathrm{VB}-\mathrm{C}_{7}: 69.6 \mathrm{nM}\left[{ }^{3} \mathrm{H}\right] \mathrm{VB}-\mathrm{C}_{7}$.

group of higher $\mathrm{MW}$, such as human tumor necrosis factor receptor $\left(\mathrm{M}_{\mathrm{r}} 100,000 \pm 5,000\right)^{23)}$, estrogen receptor $\left(M_{r} 70,000\right)^{24)}$, and interleukin-3 receptor $\left(M_{r} 65,000 \sim 70,000\right)^{25)}$, or a low $M W$ receptor such as retinoic acid binding protein $\left(M_{\mathrm{r}} 15,000\right)^{26)}$. With respect to $\mathrm{MW}$, the VB-C binding protein resembles insulin-like growth factor receptor $\left(M_{r} 31,000\right)^{27)}$ and juvenile-hormone receptor $\left(M_{r} 32,000\right)^{28)}$.

Densitometric scanning of the VB-C binding protein on native gels (Fig. 6, track 2) revealed that the binding protein comprised as high as $11.8 \%$ in the HPLC fraction. Therefore, by extraction from the native gel as shown in Fig. 7 or by affinity chromatography (Fig. 6, track 1) 6,300-fold purification should have been achieved and the pure binding protein had a specific activity of $2.5 \times 10^{8} \mathrm{dpm} / \mathrm{mg}$-protein under standard binding assay conditions. From Scatchard analysis, maximum binding activity was calculated to be 6.8 -fold higher than that under standard conditions. Thus, the binding protein should have the maximum binding of $1.7 \times 10^{9} \mathrm{dpm} / \mathrm{mg}$-protein.

\section{Effect of DNA on VB-C Binding Activity}

We have shown previously that treatment of the crude extract with DNase or RNase did not alter the VB-C binding activity. Here we checked the effect of DNA addition (Table 3). When the binding protein was incubated with genomic DNA of $S$. virginiae prior to the addition of $\left[{ }^{3} \mathrm{H}\right] \mathrm{VB}-\mathrm{C}_{7}$, the binding activity decreased reproducibly by about $40 \%$ (Expts 1 and 2). In contrast, when the DNA was added after the binding protein was ligated with the $\left[{ }^{3} \mathrm{H}\right]$ ligand, no such decrease was observed (Expt 3 ). We confirmed that the DNA alone did not show any binding activity. Furthermore, incubation of $\left[{ }^{3} \mathrm{H}\right]$ ligand with the DNA prior to the addition of the binding protein caused no decrease of the binding activity, excluding the possibility that any contaminant in the DNA preparation degraded or non-specifically adsorbed the $\left[{ }^{3} \mathrm{H}\right]$ ligand thereby decreasing the binding activity (Expts 4 and 5). Therefore, complex formation between the non-ligated binding protein and the DNA seemed essential for the decrease of the binding activity. Although at present we have no clear evidence to correlate this phenomenon with the signal transducing mechanism, it is clear that the binding protein has the ability to interact with the DNA of $S$. virginiae.

\section{Acknowledgment}

The authours are grateful to Dr. HIDEo ONO of the Applied Microbiology Laboratory of Takeda Chemical Industries, Ltd., for their assistance with the large scale cultivation, and to Prof. KENJI MoRI of Department of 
Agricultural Chemistry, the Tokyo University, for kindly providing optically active VB-A, B, B', C and D. This work is supported in part by a grant from the Ministry of Agriculture, Forestry and Fisheries.

\section{References}

1) Kleiner, E. M.; S. A. Pliner, V. S. Solfer, V. V. Onoprienko, T. A. Balashova, B. V. Rosynov \& A. S. KHOKHLOV: The structure of A-factor, a bioregulator from Streptomyces griseus. Bioorg. Khim. 2: 1142 1147, 1976

2) KнокнLov, A. S.: Problems of studies of specific cell autoregulators (on the example of substances produced by some actinomycetes). In Frontiers of Bioorganic Chemistry and Molecular Biology. Ed., S. N. ANANCHENKo, pp. $201 \sim 210$, Pergamon Press, 1980

3) HARA, O.\& T. BePPU: Mutants blocked in streptomycin production in Streptomyces griseus - The role of A-factor. J. Antibiotics 35: $349 \sim 358,1982$

4) GRÄFE, U.; W. SCHADE, I. ERITT \& W. F. FlECK: A new inducer of anthracycline biosynthesis from Streptomyces viridochromogenes. J. Antibiotics 35: 1722 1723, 1982

5) GräFe, U.; G. Reinhardt, W. Schade, I. Eritt, W. F. Fleck \& L. Radics: Interspecific inducers of cytodifferentiation and anthracycline biosynthesis from Streptomyces bikiniensis and S. cyaneofuscatus. Biotechnol. Lett. 5: $591 \sim 596,1983$

6) Kawaguchi, T.; T. Asahi, T. Satoh, T. Uozumi \& T. Beppu: B-Factor, an essential regulatory substance inducing the production of rifamycin in a Nocardia sp. J. Antibiotics 37: 1587 1595, 1984

7) Kawaguchi, T.; M. Azuma, S. Horinouchi \& T. Beppu: Effect of B-factor and its analogues of rifamycin biosynthesis in Nocardia sp. J. Antibiotics 41: 360 365, 1988

8) Kondo, S.; K. Yasul, M. Katayama, S. Marumo, T. Kondo \& H. Hattori: Structure of pamamycin-607, an aerial mycelium-inducing substance of Streptomyces alboniger. Tetrahedron Lett. 28: 5861 5864, 1987

9) Yamada, Y.; K. Sugamura, K. Kondo, M. Yanagimoto \& H. Okada: The structure of inducing factors for virginiamycin production in Streptomyces virginiae. J. Antibiotics 40: 496 504, 1987

10) Kondo, K.; Y. Higuchi, S. Sakuda, T. Nihira \& Y. Yamada: New virginiae butanolides from Streptomyces virginiae. J. Antibiotics 42: 1873 1876, 1989

11) Sato, K.; T. NiHiRa, S. SAKUdA, M. YANaGimoto \& Y. Yamada: Isolation and structure of a new butyrolactone autoregulator from Streptomyces sp. FRI-5. J. Ferment. Biotechnol. 68: 170 173, 1989

12) Ohashi, H.; Y.-H. Zheng, T. NihiRa \& Y. Yamada: Distribution of virginiae butanolides in antibiotic-producting Actinomyces, and identification of the inducing factor from Streptomyces antibioticus as virginiae butanolide A. J. Antibiotics 42: $1191 \sim 1195,1989$

13) ERITT, I.; U. GRÄFE \& W. F. FLECK: Inducers of both cytodifferentiation and anthracycline biosynthesis of Streptomyces griseus and their occurence in actinomycetes and other microorganism. Z. Allg. Mikrobiol. 24: $3 \sim 12$, 1984

14) Kim, H. S.; T. Nihira, H. Tada, M. Yanagimoyo \& Y. Yamada: Identification of binding protein of virginiae butanolide $\mathrm{C}$, an autoregulator in virginiamycin production, from Streptomyces virginiae. J. Antibiotics 42 : $769 \sim 778,1989$

15) Yanagimoto, M. \& G. Terui: Physiological studies on staphylomycin production. J. Ferment. Technol. 49: $604 \sim 610,1971$

16) Yanagimoto, M. \& G. Terui: Physiological studies on staphylomycin production. II, formation of a substance effective in inducing staphylomycin production. J. Ferment. Technol. 49: 611 618, 1971

17) Nihira, T.; Y. ShimizU, H. S. Kim \& Y. YAMAda: Structure-activity relationships of virginiae butanolide C, an inducer of virginiamycin production in Streptomyces virginiae. J. Antibiotics 41: 1828 1837, 1988

18) MORI, K. \& N. CHIBA: Synthetic microbial chemistry XXIII - Synthesis of optically active virginiae butanolides A, B, C and D, and other autoregulators from Streptomycetes. Liebigs Ann. Chem. 1990: 31 37, 1990

19) Hunter, I. S.: Gene cloning in Streptomyces. In DNA Cloning Volume II. Ed., D. M. GLover, pp. 19 44, IRL Press, 1985

20) Cuatrecasas, P.: Protein purification by affinity chromatography - Derivatization of agarose and polyacrylamide beads. J. Biol. Chem. 245: 3056 3065, 1970

21) Rousseau, G. G.; J. D. Baxter \& G. M. Tomkins: Glucocorticoid receptors. Relations between steroid binding and biological effects. J. Mol. Biol. 67: 99, 1972

22) Miyake, K.; S. Horinouchi, M. Yoshida, N. Chiba, K. Mori, N. Nogawa, N. Morikawa \& T. Beppu: Detection and properties of A-factor-binding protein from Steptomyces griseus. J. Bacteriol. 171: 4298 4302, 1989

23) Gregory, B. S.; R. A. Aiyer \& B. B. Aggarwal: Human tumor necrosis factor-receptor. J. Biol. Chem. 263: $19098 \sim 19104,1988$

24) Lubahn, D. B.; K. S. MCCARTY, Jr. \& K. S. MCCARTY, Sr.: Electrophoretic characterization of purified bovine, porcin, murine, rat, and human uterine estrogen receptors. J. Biol. Chem. 260: 2515 2526, 1985 
25) MAY, W. S. \& J. N. IHLE: Affinity isolation of the interleukin-3 surface receptor. Biochem. Biophys. Res. Commun. 135: $870 \sim 879,1986$

26) Bailey, J. S. \& C. H. Siv: Purification and partial characterization of a novel binding protein for retinoic acid from neonatal rat. J. Biol. Chem. 263: 9326 9332, 1988

27) Busby, W. H.; D. G. KlapPeR, Jr. \& D. R. Clemmons: Purification of a 31,000-dalton insulin-like growth factor binding protein from human amniotic fluid. J. Biol. Chem. 263: 14203 14210, 1988

28) Ozyhar, A. \& M. Kochman: Juvenile-hormone binding protein from the hemolymph of Galleria mellonella (L). Eur. J. Biochem. 162: 675 682, 1987 